\title{
VARIATIONS IN THE PROPERTIES OF COPPER-ALUMINA NANOCOMPOSITES SYNTHESIZED BY MECHANICAL ALLOYING
}

\author{
VARIIRANJE LASTNOSTI BAKER-ALUMINIJEVIH OKSIDNIH \\ KOMPOZITOV, SINTETIZIRANIH Z MEHANSKIM LEGIRANJEM
}

\author{
Lakshmi Narasimhan Rajeshkumar ${ }^{1 *}$, Koduvayur Sankaranarayanan Amirthagadeswaran ${ }^{2}$ \\ ${ }^{1}$ KPR Institute of Engineering and Technology, Arasur, Coimbatore - 641407, Tamilnadu, India \\ ${ }^{2}$ United Institute of Technology, Periyanaickenpalayam, Coimbatore - 641020, Tamilnadu, India
}

Prejem rokopisa - received: 2018-06-19; sprejem za objavo - accepted for publication: 2018-09-13

doi:10.17222/mit.2018.122

\begin{abstract}
Industries use metal-matrix composites all year round, where the alloying of metals plays an important role. Many researchers have seen that an improvement in the alloying of metals possesses a great value in applications. So metal-matrix composites are being investigated for better blending of the particles for the metal constituents. This guides researchers towards the addition of many alloying elements or reinforcements to form superior-quality MMCs with smaller particle sizes. In this regard, the focus of the present work is to reinforce alumina with copper synthesized and blended using a high-energy ball milling. The powders were compressed by cold compaction at a pressure of $174 \mathrm{MPa}$ and sintered at $950{ }^{\circ} \mathrm{C}$. Separate green compacts were formed from each of the powders that were milled for different time periods, such as $(3,6,9,12,15)$ h. X-Ray diffraction (XRD) and scanning electron microscopy (SEM) were used to determine the particle size of the powders and the dominant processes during the milling, respectively. The wear and corrosion behaviours of each specimen were investigated in accordance with the ASTM G99-17 and ASTM G44-99 standards, respectively. The results clearly show that as the particle sizes of the powders reduce, the wear and corrosion rates decrease. The properties were found to be the best for the compacts formed from powders milled for $12 \mathrm{~h}$.
\end{abstract}

Keywords: copper, alumina, ball milling, wear, corrosion

Industrijska uporaba kompozitov z osnovo iz kovinskih zlitin (MMCs) igra pomembno vlogo. Mnogi raziskovalci so spoznali, da izboljšanje legiranja pomeni pomemben napredek za njihovo uporabnost. Tako na področju kompozitov s kovinsko osnovo raziskujejo predvsem postopke, s katerimi bi lahko v kovinsko osnovo vmešali čim bolj enakomerno najbolj fine keramične delce. Raziskovalci poizkušajo kompozitom z osnovo iz kovinskih zlitin (MMCs) dodajati različne legirne elemente $\mathrm{v}$ obliki ojačitvene faze, da bi dobili čim boljšo kakovost kompozitov z zelo majhnimi delci. V tej zvezi so avtorji pričujoče raziskave sintetizirali kompozit na osnovi bakra in Al oksida z visoko energijskim krogličnim mlinom pri različno dolgem času mletja: (3, 6, 9, 12 ali 15) h. Prahove so po mletju hladno kompaktirali pri tlaku $174 \mathrm{MPa}$ in sintrali pri $950{ }^{\circ} \mathrm{C}$. $\mathrm{Z}$ rentgensko difrakcijo (XRD) in vrstičnim elektronskim mikroskopom (SEM) so določili velikost delcev oz. prevladujoč proces med krogličnim mletjem. Nato so določili odpornost proti obrabi izdelanih kompozitov v skladu s standardoma ASTM G99-17 in ASTM G44-99. Rezultati raziskav so jasno pokazali, da se z zmanjšanjem velikosti delcev zmanjša hitrost obrabe in korozije. Najboljše lastnosti so dosegli na vzorcih kompozitov, katerih prahovi so bili mleti 12 ur.

Ključne besede: baker, aluminijev oksid, kroglično mletje, obraba, korozija

\section{INTRODUCTION}

Metal-matrix composites are tailor-made materials that give improved properties when used in combination, but these properties might not be achieved when the materials exist alone. Copper-alumina $\left(\mathrm{Cu}-\mathrm{Al}_{2} \mathrm{O}_{3}\right)$ composites are characterized by the stiffness of the copper and the hardness of the alumina, which provides the composites with good wear resistance along with an excellent electrical conductivity. Due to the poor wettability of copper-alumina composites, they are generally manufactured using the squeeze-casting or gas-infiltration techniques, since the wetting angle of copper with alumina is very small, lying between $124^{\circ}$ and $170^{\circ}$. Copper oxide can be added to the pure copper to increase the wettability. This increases the possibility of alumina

*Corresponding author e-mail:

*1rkln27@gmail.com being incorporated into the copper matrix with ease, without any form of external pressure. ${ }^{1}$ But the formation of aluminates at the boundary of the matrix and reinforcement is a major drawback that reduces the interfacial strength., 2,3 There will also be some residual stresses due to the variation of the thermal expansion coefficient (tensile in copper and compression in alumina) at the interface being setup due to cooling of the composites after infiltration. ${ }^{4,5}$ Research focus has been given to this interesting fact, as it greatly affects the mechanical and thermal behaviours of copper-alumina composites. Research into rapidly solidified and mechanically alloyed copper-based composites has given significant results and so the chances of using them in marine and some other floating vessels have increased. Besides the usage of precipitation- and dispersion-hardened copper alloy composites in the current applications, it can also be applied in rocket parts, electrical and 
electronic parts, potential usage in the first wall of a fusion reactor, turbine blades and a shield for neutron radiation. ${ }^{6}$ Generally, the copper is reinforced with oxides, carbides and borides for better mechanical and tribological properties. These metal borides generally have a low solubility in copper and the excess of the secondary formed elements precipitates, thus affecting the conductivity of the copper.

The process of the formation of metal oxides as a product of the corrosion of the whole metal substrate is called internal oxidation. These oxides are quarantined from the substrate after being formed. ${ }^{7}$ Usually, when some of the constituents of the alloy are oxidized, besides the whole substrate, internal oxidation occurs. As far as copper-alumina composites are concerned, the oxidation of aluminium in the whole of the copper medium may occur and also an aggressive oxidation may possibly occur when aluminium atoms come directly into contact with oxygen. ${ }^{8}{ }^{8}$ These oxidation reactions should be taken care of by the internal oxidation mechanism in order to have a better consolidation and the prevention of loss of important properties. Mechanical alloying (MA) is a materials-processing method in the solid state that involves the repeated welding, fracturing, and re-welding of a blend of powder particles, generally in a high-energy ball mill, to produce a very fine microstructure. ${ }^{10}$ Some alloying elements with a rare possibility of synthesis by conventional melting methods can be synthesized by MA with ease. The MA process can be considered as a means of consolidating the metals or alloys, which may form a solid solution, with a predictable microstructure. ${ }^{11,12}$ The process of mechanical alloying was originally developed as a means of producing oxide dispersion-strengthened alloys (ODS). By using MA, homogeneity is dictated by the size of the particle, but contamination and fire hazards are some issues with respect to smaller particle sizes. ${ }^{13-15}$

Currently, copper-oxide-based marine-antifouling coatings are not advisable for ship hulls with aluminium as a base metal. This is due to the fact that when copper settles down on the aluminium hull, a galvanic cell is formed with copper as the cathode and aluminium as the anode, as shown in Figure 1. ${ }^{16,17}$ Sea water acts as an electrolyte for this phenomenon, due to which corrosion occurs at a rapid rate. A major type of galvanic corrosion induces pitting on the corroded surface. Usually, with two dissimilar metals, when present in an electrolytic medium, an electric potential arises, thus forming a galvanic cell. In galvanic corrosion, the anode (active metal) undergoes rapid corrosion, while the cathode (noble metal) undergoes slower corrosion, as the galvanic coupling protects it. The corrosion rate of the active metal would be faster than its corrosion rate when present separately. A galvanic series is generally formed to measure the corrosion potential of metals and alloys in sea water or salt water, which can be ordered as galvanic series. ${ }^{18-20}$ The metal present at the higher level of the

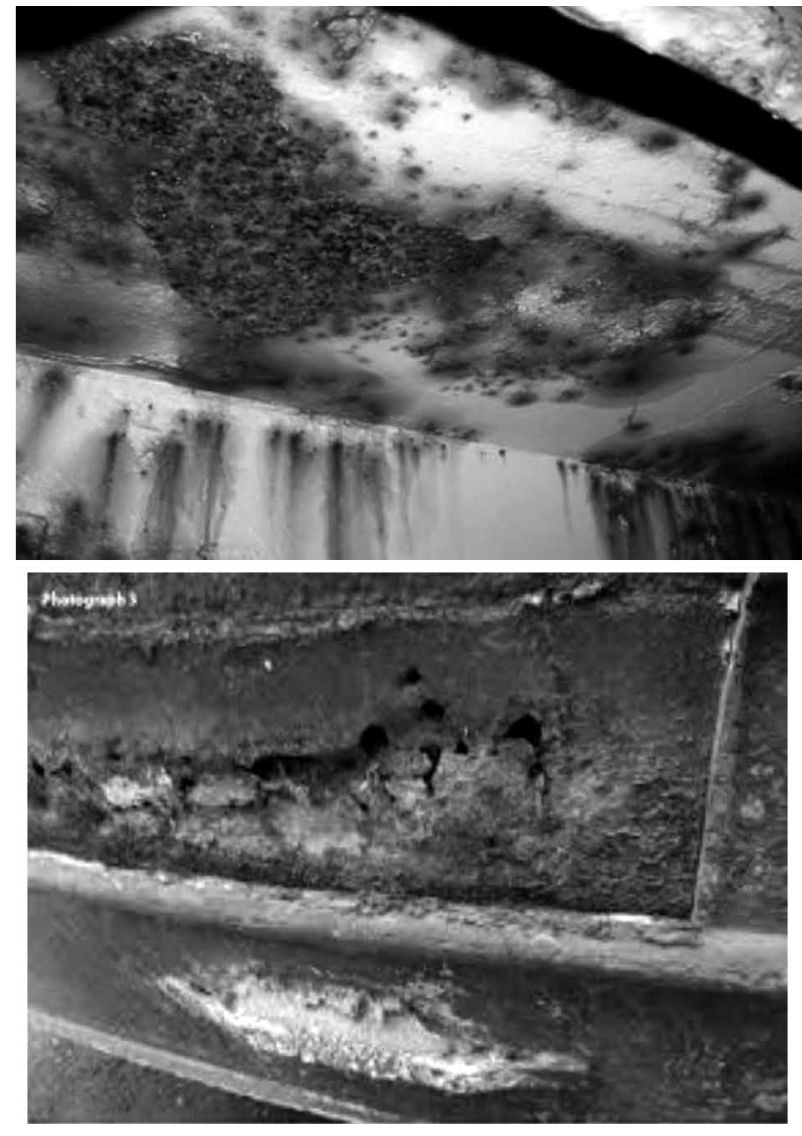

Figure 1: Corrosion in ship hull and cover plate

series shows greater resistance towards corrosion, while the metals present at the lower levels show lesser resistance. Since aluminium is present at the bottom of the series, it is less susceptible to galvanic corrosion. ${ }^{18}$

In the present work, $\mathrm{Cu}-\mathrm{Al}_{2} \mathrm{O}_{3}$ composites were synthesized by MA in a high-energy ball mill to form nanocomposites. XRD and SEM were used to characterize the milled powders for particle size and dominant process, respectively. The specimens were compacted and sintered, and then tested for wear and corrosion behaviour. The study focused on the influence of particle size on the behaviour of composites.

\section{EXPERIMENTAL PART}

Copper and alumina powders were purchased from $\mathrm{M} / \mathrm{s}$ Nice Chemicals (P) limited, Kochi, with a standard particle size of 325 mesh and 625 mesh $(44 \mu \mathrm{m}$ and $20 \mu \mathrm{m})$, respectively. The manufacturing of copper-alumina composites by means of powder metallurgy comprises various steps, like mechanical alloying, preheating, compaction and sintering. Alumina is mixed with copper in $10 \%$ and $15 \%$ by weight, with the remainder being copper. The materials are added to the ball mill with a ball-to-powder ratio (BPR) of 10:1. Toluene is added as the process control agent (PCA), as per requirements, into the vials. The speed of the sun wheel and the 
planet wheels, to which the vial is attached, were set in the ratio 1:4. The sun and planet wheels' direction of rotation is contradicting to each other, as per the time setting, which in the current experiment is $15 \mathrm{~s}$. The defined speed of rotation for every cycle was $120 \mathrm{~min}^{-1}$. These process standards were maintained for various milling durations $(3,6,9,12,15) \mathrm{h}$. In order to dissipate the heat from the vials generated due to friction, they were set to be idle for $15 \mathrm{~min}$ after each continuous run of $75 \mathrm{~min}$. The complete setup of the ball mill is shown in a figure.

At the bottom of the crucible the powders from the vials would settle down, and were then filtered using a filter paper to remove excess toluene. In order to make the powders ready for compaction, they were preheated to $75{ }^{\circ} \mathrm{C}$ for about $30 \mathrm{~min}$. These powders were then moved to a uni-axial forging die that was coated with graphite as a lubricant. The primary requirement of the lubricating agent was to eliminate the powder from sticking to the inner side of the die and to assist in equal and uniform compaction. The pressure for the compaction was $135 \mathrm{MPa}$ and the plunger was held for $3 \mathrm{~min}$. The green compacts were transferred to an electric furnace for sintering. The sintering temperature was $950{ }^{\circ} \mathrm{C}$ and the time of holding at this temperature was about $1 \mathrm{~h}$. The temperature of the furnace was gradually increased at a rate of $12{ }^{\circ} \mathrm{C}$ per hour and the compacts, after being sintered, were furnace cooled. The compacted powders were characterized by XRD and SEM for particle size and dominant processes, respectively.

\subsection{XRD and SEM images}

The main objective of the XRD technique is to characterize the powders for their particle size based on the peaks obtained. In the current work a total of ten samples were characterized by XRD, which were collected at various milling time periods, like $(3,6,9,12$, 15) h. Standard practices were used for the XRD analysis. About of $100 \mathrm{mg}$ of powders were taken from every sample and evaluated. The powders were closely packed in a glass slit of size $12 \mathrm{~mm} \times 12 \mathrm{~mm} \times 2 \mathrm{~mm}$. The measurements of XRD were carried out using an $\mathrm{XPert}^{3}$ Powder machine with $\mathrm{Cu}-\mathrm{K}_{\mathrm{a}}$ radiation $\left(K_{\alpha}=\right.$ $0.154056 \mathrm{~nm}$ ). While carrying out the test, the samples were held rigid and the X-ray tubes rotated from $10^{\circ}$ to $90^{\circ}$ with a scanning range of $10^{\circ} \% \mathrm{~min}$. The values obtained from the XRD analyses were used to calculate the particle size and strain induced on the surface of the powders. The calculations were based on the Williamson-Hall equation, as given in Equation (1).

$$
\beta \cos \theta=\mathrm{k} \lambda / \mathrm{t}+4 \varepsilon \sin \theta
$$

where $k$ is the shape factor (value $=0.5$ ), $\lambda$ is the wavelength of the X-rays (value $0.15406 \mathrm{~nm}$ ). A plot between $\beta \cos \theta$ ( $y$-axis) and $4 \sin \theta$ ( $x$-axis) would render a straight-line equation in which the slope $(\mathrm{m})$ could be equated to the lattice strain directly and the intercept (c) could be used to calculate the particle size $(t)$ by using the following relation: $c=k \lambda / t$.

The SEM produces images from the samples through scanning the specimen with the support of a focused electron beam. The milled powders were evaluated using a FE-SEM model Carl Zeiss Microscope to identify the dominant process after each cycle of milling. The current study helps to converge the result that the particle size cannot be downsized beyond steady state.

\subsection{Wear behaviour}

The specimens were prepared as pins of dimensions $\varphi 10 \mathrm{~mm} \times 30 \mathrm{~mm}$, as necessary for the wear test. The tests were conducted in the prevailing atmospheric conditions, according to ASTM G99-17 in a CONMAT Pin-on-Disc tester, shown in Figure 2. Before starting the test and after each test the counter-facing disc in the equipment was polished with both coarse- and fine-grade emery paper. In most of the cases the sliding-wear tests were carried out in dry conditions with a load of 2-4 kg and a speed of 300-600 $\mathrm{min}^{-1}$ in optimum conditions. As per the inferences drawn from the literature, an applied load of $3 \mathrm{~kg}$ and a disc speed of $400 \mathrm{~min}^{-1}$ were maintained. Accordingly, the sliding distance and the sliding speed were found to be $4150 \mathrm{~m}$ and $2.31 \mathrm{~m} / \mathrm{s}$, respectively. All the parameters were kept constant while testing the wear behaviour of the specimen.

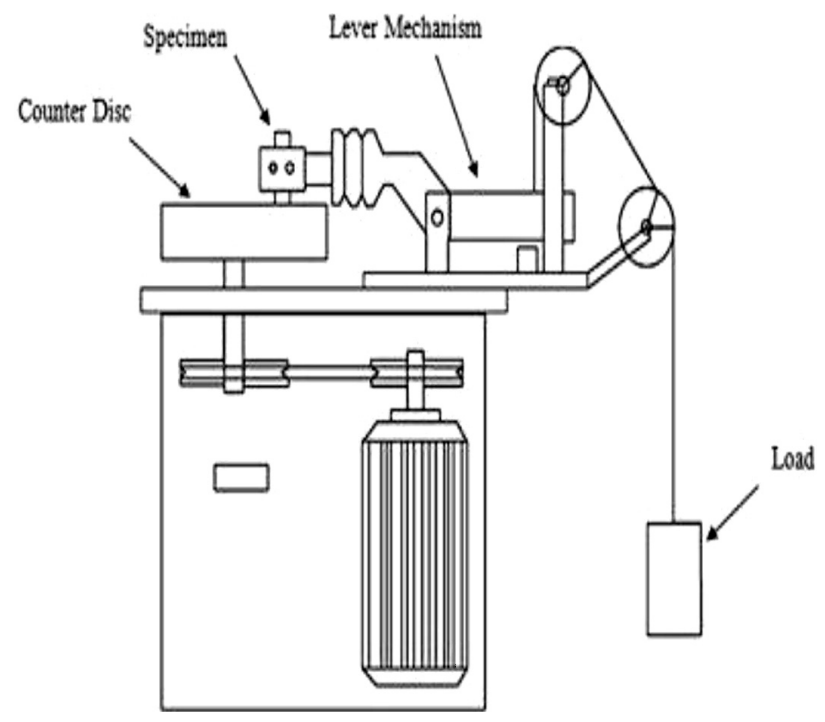

Figure 2: Pin-on-disc equipment ${ }^{21}$

\subsection{Corrosion behaviour}

As per the ASTM standard G44-99, a $3.5 \% \mathrm{NaCl}$ standard corrosion test was carried out on the specimen with dimensions of $15 \mathrm{~mm} \times 15 \mathrm{~mm} \times 10 \mathrm{~mm}$. The specimen was polished with various grades of sand paper like 180, 240, 300 and 400 grit and then polished again in a double-disc polishing machine for a finer surface finish. Soapy water was used as the surface-cleansing 


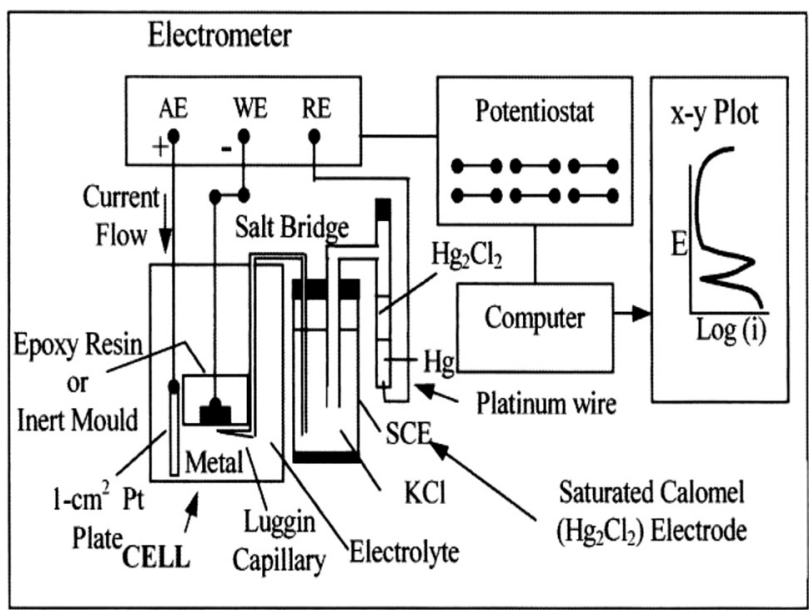

Figure 3: Potentiodynamic polarizer ${ }^{22}$

agent, after which the specimens were rinsed with distilled water. Polarization tests were performed in PGP 201 potentiostat-galvanostat equipment, as shown in Figure 3, with a standard scan rate of $166.7 \mu \mathrm{V} / \mathrm{s}$. The electrolyte used was made of $3.5 \% \mathrm{NaCl}$ solution.

\section{RESULTS AND DISCUSSION}

\subsection{Particle size variation}

The samples were designated with the codes S15X and S10X for ease of representation. The first letter ' $\mathrm{S}$ ' stands for 'specimen', the next two digits '10' and '15' represent the weight percentage of alumina in the specimen, and the last digit represents the milling duration in order, i.e., $(3,6,9,12,15) \mathrm{h}$ as $1,2,3,4$ and 5 , respectively.

The particle size of the milled powders was calculated using the Williamson-Hall equation, as stated above. X-ray peak broadening could be observed during each milling cycle, representing the reduction in the particle size. This was due to the defects induced on the surface of the powders as a result of colliding with the hardened steel balls during the milling. A shift in the X-ray peaks towards the left of the axis could also be observed as the time of the milling increased. This phenomenon occurs as a result of homogenization of the oxide particles into the copper matrix. As the hours of milling increased, the prominent peaks of alumina disappeared because of the uniform dispersion of the hard ceramic $\gamma$ alumina particles within the copper matrix. The lattice strain denotes the rate of strain induced on the surface of the particle to create a defect in the lattice structure of the particle. Accordingly, the percentage of lattice strain increases when the particle size decreases. The XRD results of the powders with the minimum particle size are shown in Figure 4.

The variation of the particle size for both classes of specimen is shown in Table 1. It can be observed that after $(3,6,9,12) \mathrm{h}$ of milling the particle size reduces
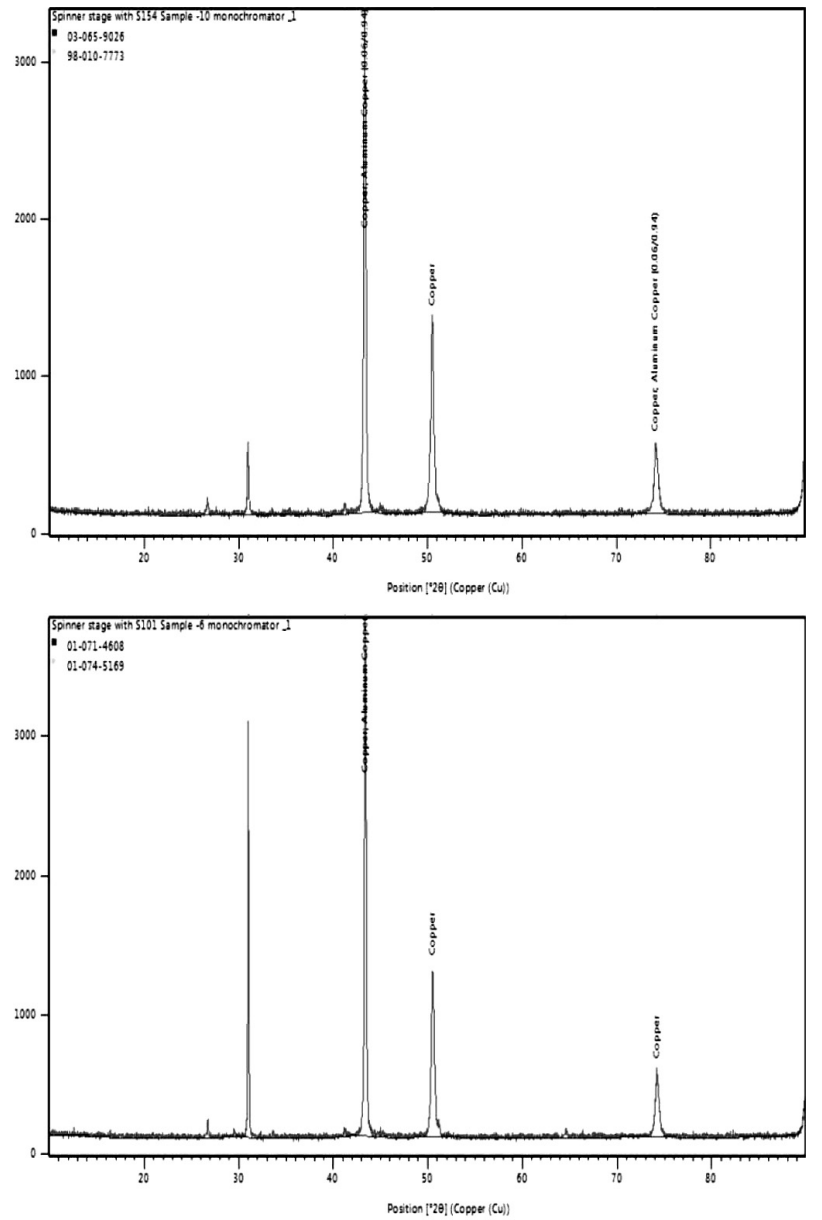

Figure 4: a) XRD peaks of S154, b) XRD peaks of S104

for the blended powders due to the dominance of the fracture on the surface of the powders. In contrast, after $15 \mathrm{~h}$ of milling the particle size increases because of cold welding between the particles. As the particles stick together, the average particle size increased. Since cold welding was predominant during $15 \mathrm{~h}$ of milling, the milling cycle was stopped. It was noted that it reached saturation and no further reduction in the particle size was possible. It could be deduced from the analysis that the fracture and cold welding occurred during milling and reached a steady state after $15 \mathrm{~h}$ of the milling cycle. SEM images show the dominant process of milling and the variation in the particle size, as shown in Figure 5.

Table 1: Variation in particle size for $S 15 x$ and $S 10 x$

\begin{tabular}{|c|c|c|c|c|c|c|}
\hline $\begin{array}{c}\text { Milling } \\
\text { duration } \\
(\mathrm{h})\end{array}$ & Sample & $\begin{array}{c}\text { Particle } \\
\text { size } \\
(\mathrm{nm})\end{array}$ & $\begin{array}{c}\text { Lattice } \\
\text { strain } \\
(\%)\end{array}$ & Sample & $\begin{array}{c}\text { Particle } \\
\text { size } \\
(\mathrm{nm})\end{array}$ & $\begin{array}{c}\text { Lattice } \\
\text { strain } \\
(\%)\end{array}$ \\
\hline $\mathbf{3}$ & $\mathrm{S} 151$ & 287 & 0.18 & $\mathrm{~S} 101$ & 318 & 0.16 \\
\hline $\mathbf{6}$ & $\mathrm{S} 152$ & 154 & 0.21 & $\mathrm{~S} 102$ & 186 & 0.22 \\
\hline $\mathbf{9}$ & $\mathrm{S} 153$ & 106 & 0.35 & $\mathrm{~S} 103$ & 118 & 0.32 \\
\hline $\mathbf{1 2}$ & $\mathrm{S} 154$ & 91 & 0.39 & $\mathrm{~S} 104$ & 99 & 0.44 \\
\hline $\mathbf{1 5}$ & $\mathrm{S} 155$ & 120 & 0.26 & $\mathrm{~S} 105$ & 131 & 0.38 \\
\hline
\end{tabular}




\subsection{Wear behaviour}

Wear tests were conducted on the S15x series of specimens for the copper-alumina composites and the results were consolidated. The wear (in microns) was read directly from the interface display, while the sliding speed and load were kept constant for all the tests. A speed of $400 \mathrm{~min}^{-1}$ and a load of $3 \mathrm{~kg}$ were maintained, for which the corresponding sliding distance was calculated as $4150 \mathrm{~m}$. The readings are tabulated in Table 2. The variation of the wear rate of the copper-alumina composites, as shown in Figure 7a, can be directly attributed to the variation of the particle size. SEM images of the worn surface of the composites are shown in Figure 6, from which the following inferences could be drawn.

The hardness values for the specimen, as tabulated in Table 2, increase when the particle size decreases, due to the specific area occupied by the particles. But at $15 \mathrm{~h}$ of milling, due to many loose fragments, the hardness value decreases. For pure copper the hardness value is $35 \mathrm{BHN}$ and the obtained results are almost the same as the available results.

This behaviour is clearly on par with the variation of the wear rate of copper-alumina composites. The wear rate of the composites was found to vary according to the dominant process (fracture and cold welding) during milling. At the time of compaction and sintering the cold-welded particles occupied a high specific area and the formed composites were porous. It could be observed from the images that wear tracks were neither formed
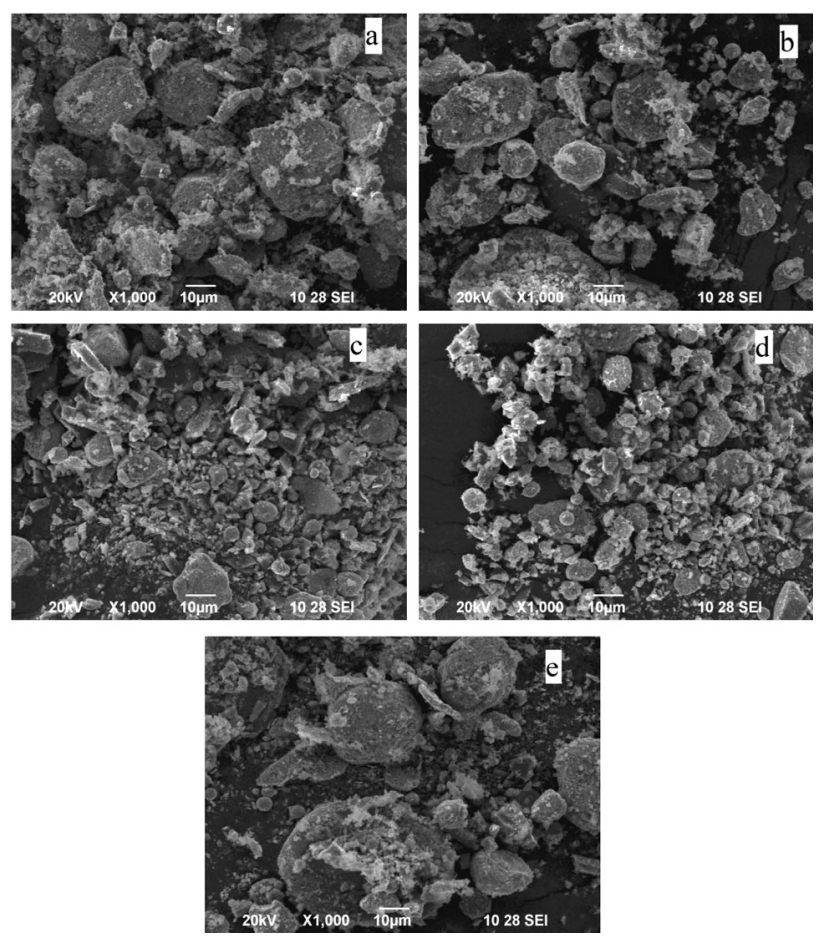

Figure 5: SEM images of milled powders: a) S101, b) S102, c) S103, d) $\mathrm{S} 104$, e) $\mathrm{S} 105$ nor clear on the composite surface formed by the cold-welded particles. This could be observed from Figure 6b. In contrast, from the composites formed by fractured particles, smears on the worn surfaces could be seen, indicating the proper response of the composites with respect to the wear pin. Since the amount of debris formed is a minimum, it could not be analysed separately for its nature by SEM and XRD. In general, the black colour of the wear debris probably indicates the formation of copper oxide during the wear phenomenon. It could be observed from Figure 6a that the smears are quite high due to the presence of loose alumina in the composites. These particles are easily pulled out from the composite surface, inducing the abrasive wear. At higher particle sizes the interfacial strength of the copper-alumina composites is comparatively lower. This increases the wear rate as the presence of micro cracks is greater in larger particles. As the particle size reduces, the homogeneity of the composites increases as the alumina is embedded properly in the copper matrix and could not be pulled out.

Table 2: Experimental Wear rate

\begin{tabular}{|c|c|c|c|c|}
\hline Sample & $\begin{array}{c}\text { Speed } \\
\left(\mathrm{min}^{-1}\right)\end{array}$ & $\begin{array}{l}\text { Distance } \\
(\mathrm{m})\end{array}$ & $\begin{array}{l}\text { Wear } \\
(\mu \mathrm{m} / \mathrm{m})\end{array}$ & $\begin{array}{c}\text { Hardness } \\
\text { (BHN) }\end{array}$ \\
\hline 151 & \multirow{5}{*}{400} & \multirow{5}{*}{4150} & 1.987 & 30.17 \\
\hline 152 & & & 1.456 & 30.79 \\
\hline 153 & & & 0.771 & 32.21 \\
\hline 154 & & & 0.525 & 34.62 \\
\hline 155 & & & 0.929 & 31.93 \\
\hline
\end{tabular}

From the XRD it is clear that the alumina is thoroughly embedded into the copper matrix after $12 \mathrm{~h}$ of milling. From Figures $\mathbf{6 c}$ and $\mathbf{6 d}$ the adhesive-wear phenomenon could be observed due to the ductile nature of the copper. The wear tracks show smeared edges and the smearing is due to the plastic deformation of the copper dominant composite surface against the disc. The wear tracks were discontinuous and shallow in both the images, but the coarser grains in S153 led to higher wear than S154, which had finer grains by comparison. Again, the wear rate increases for S155 since the dominant process was the cold welding of particles, which could be attributed to more flakes being formed, as seen in Figure 6e.

Unlike the inferences drawn by J. Winzer et al., as the content of copper and alumina remains the same for all the specimens, the influence of the presence of copper over the wear rate was not observed. ${ }^{12}$

\subsection{Corrosion behaviour}

The corrosion rates of the samples were measured using the potentiodynamic polarization method by plotting a graph between the corrosion current $\left(I_{\text {corr }}\right)$ and the corrosion voltage $\left(E_{\text {corr }}\right)$. It could be seen that due to oxidation of the base metal, as the current increases, the 


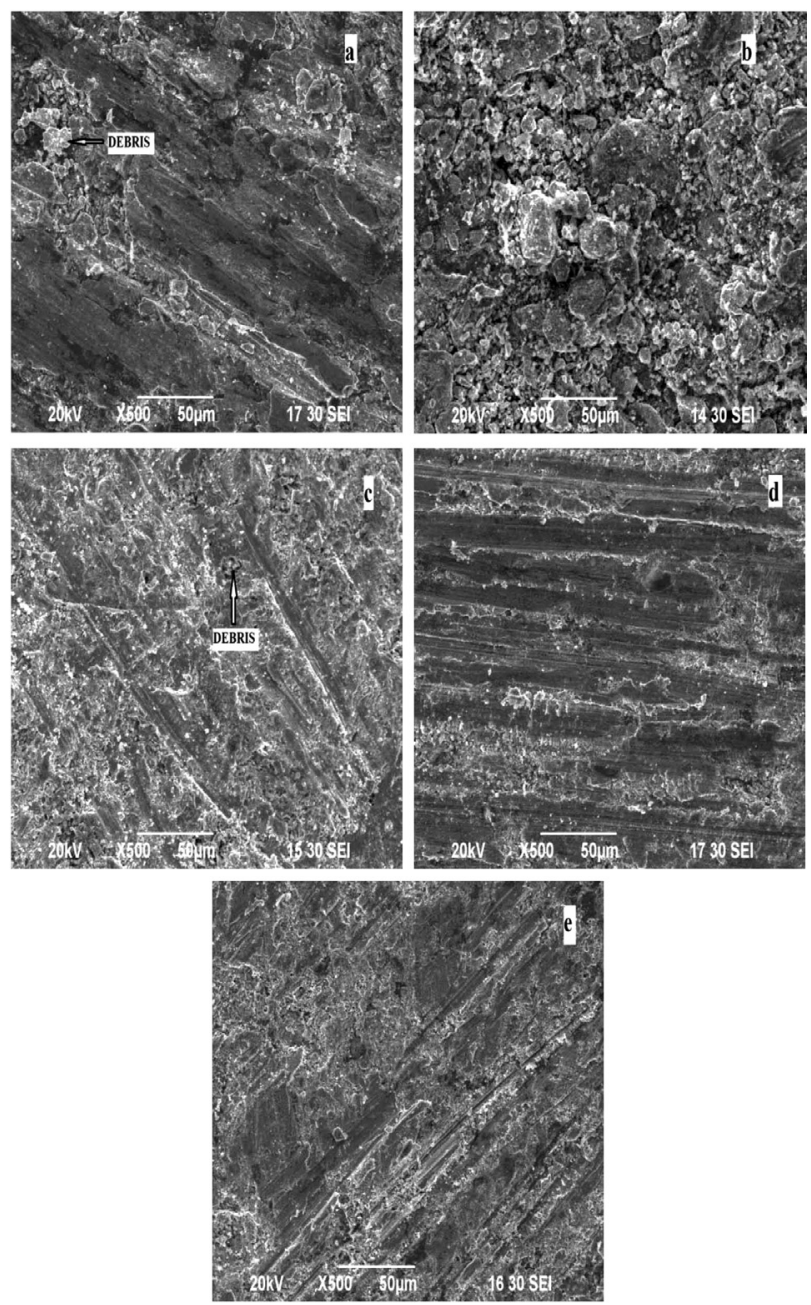

Figure 6: SEM images of worn surface: a) S151, b) S152, c) S153, d) S154, e) S155

voltage also increases. The corrosion rate of the composite is calculated using the following equation:

$$
C R(\mathrm{mpy})=\frac{1.29 \times 10^{5}\left(I_{\text {corr }}\right)(E W)}{\rho A}
$$

where $E W=$ the equivalent weight of the base metal, $\rho=$ the density of the metal, and $A=$ the area of exposure. The calculated values of the corrosion rate are displayed in Table 3, and its variation was shown in Figure $\mathbf{7 b}$. The corrosion rate is measured in millimetres per year (mmpy) in the current work.

Table 3: Corrosion test results

\begin{tabular}{|c|c|c|c|c|}
\hline Materials & $\begin{array}{c}\text { Icorr } \\
(\mu \mathrm{A})\end{array}$ & $\begin{array}{c}\text { Ecorr } \\
(\mathrm{mV})\end{array}$ & $\begin{array}{c}\text { Corrosion } \\
\text { rate } \\
(\mathrm{mmpy})\end{array}$ & $\begin{array}{c}\text { Polarization } \\
\text { resistance } \\
(\Omega)\end{array}$ \\
\hline $\mathrm{S} 101$ & 189.5 & -240.6 & 15.75 & 13.56 \\
\hline $\mathrm{S} 102$ & 162.6 & -229.8 & 7.90 & 19.39 \\
\hline $\mathrm{S} 103$ & 151.9 & -230.6 & 7.13 & 22.18 \\
\hline $\mathrm{S} 104$ & 128.4 & -198.3 & 3.66 & 26.82 \\
\hline $\mathrm{S} 105$ & 141.2 & -208.9 & 4.49 & 17.64 \\
\hline
\end{tabular}
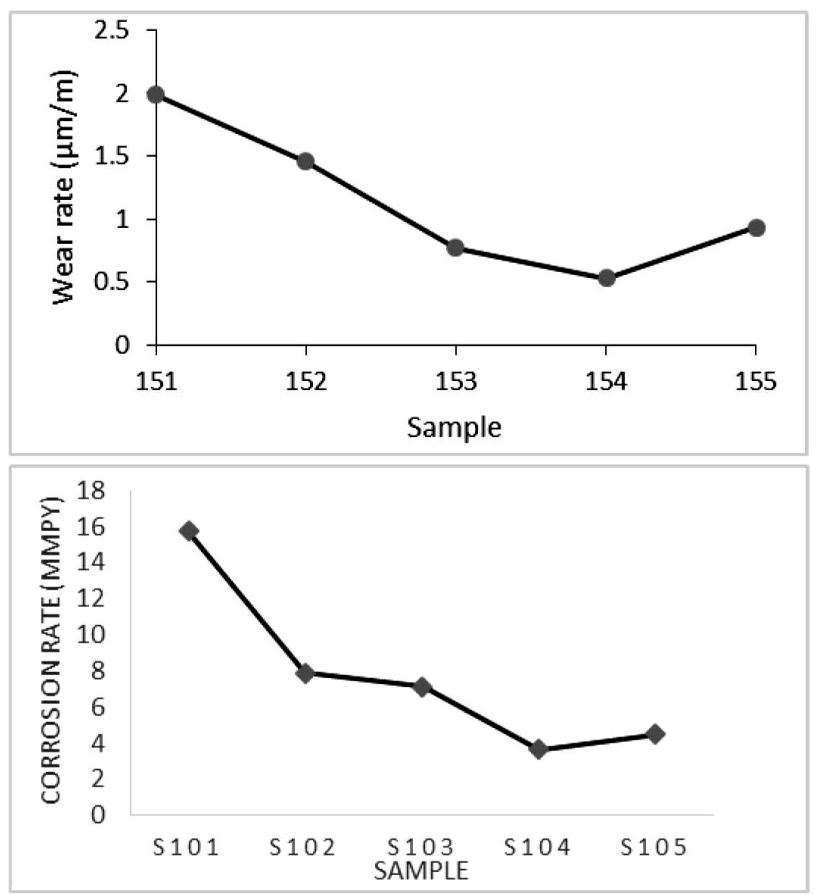

Figure 7: a) variation of the wear rate, b) variation of the corrosion rate

It could be observed from the values that as the particle size reduces the corrosion resistance increases. This may be due to the fact that the effective area occupied by the particles on the surfaces exposed to the saline medium is less. Primarily, copper-alumina composites undergo corrosion by the formation of one of the following compounds: cuprous chloride $(\mathrm{CuCl})$, which is an unstable compound; cupric chloride $\left(\mathrm{CuCl}_{2}\right)$, which forms due to further chlorination of unstable cuprous chloride; and the oxidation of copper to form any of the copper oxides. The formation of cupric chloride can be observed by the formation of a green-coloured layer over the exposed surface. Using these reactions the copper ions are removed from the surface of the composites and thus localized pits are formed as a result of prolonged exposure to the $3.5 \% \mathrm{NaCl}$ solution. Besides this, the presence of alumina induces the formation of a passive oxide layer over the surface of the composite in the presence of chloride ions. Due to this, the formation of copper chlorides and oxides is delayed, thus saving the copper ions from leaving the surface. This phenomenon continues to increase the corrosion resistance of the copper-alumina composites up to sample S104. This could be clearly seen from the polarization resistance values. But beyond that, as the alumina particles are homogenously dispersed in the copper matrix due to the milling cycle (as observed from the XRD peaks), the time for the formation of the passivating layer is the very minimum. In the meantime, more copper chlorides and oxides are formed, causing more pits on the surface. Thus, the polarization resistance value decreases, resulting in a high rate of corrosion for S105. From this 
it could be inferred that prolonged milling cycles (more than $12 \mathrm{~h}$ ) decrease the corrosion resistance of the copper-alumina composites.

\section{CONCLUSIONS}

Copper-alumina nanocomposites were prepared by mechanical alloying in a high-energy ball mill and the corrosion and wear behaviours were investigated. The samples subjected to wear and corrosion tests were prepared by using powders milled for $(3,6,9,12,15) \mathrm{h}$ and the following conclusions were drawn.

- The particle sizes of the powders were reduced to the nanoscale by mechanical alloying and the minimum particle size obtained was $91 \mathrm{~nm}$ for S154 and $99 \mathrm{~nm}$ for S104. The fracture and cold-welding processes were found to occur alternatively during the milling cycles.

- Wear studies indicated that the lowest wear rate of $0.525 \mu \mathrm{m} / \mathrm{m}$ was observed for the sample with $15 \%$ alumina, milled for $12 \mathrm{~h}$. It could also be observed from the SEM images that when the particle size reduces, the wear rate decreases, and the mechanism of wear was adhesive wear.

- The rate of corrosion also followed the same trend as the wear rate and the minimum corrosion rate of $3.66 \mathrm{mmpy}$ were found to occur for the sample with $10 \%$ alumina milled for $12 \mathrm{~h}$. The formation of oxides of alumina increased the resistance towards corrosion.

- The related application for the copper-alumina composites may be suitable for ship hull sheaths, marine aquaculture nets and as protection against the bio-fouling of underwater pipes, where both wear and corrosion resistance play a vital role.

\section{REFERENCES}

${ }^{1}$ S. Sivasankaran, K. Sivaprasad, R. Narayanasamy, P. V. Satyanarayana, X-ray peak broadening analysis of AA 6061100-x-x wt.\% $\mathrm{Al}_{2} \mathrm{O}_{3}$ nanocomposite prepared by mechanical alloying, Mater. Charac., 62 (2011), 661-672, doi:10.1016/j.matchar.2011.04.017

${ }^{2}$ J. Ruzic, J. Stasic, V. Rajkovic, D. Bozic, Synthesis, microstructure and mechanical properties of $\mathrm{ZrB}_{2}$ nano and micro particle reinforced copper matrix composite by insitu processing, Mater. Des. 62 (2014), 409-415, doi:10.1016/j.matdes.2014.05.036

${ }^{3}$ F. Bagley, M. Atlar, A. Charles, C. Anderson, The use of copperbased antifoulings on aluminium ship hulls, Ocean Eng., 109 (2015), 595-602, doi:10.1016/j.oceaneng.2015.09.044

${ }^{4}$ S. Sivasankaran, K. Sivaprasad, R. Narayanasamy, V. Kumar Iyer, Synthesis, structure and sinterability of 6061 AA100-x-x wt.\% TiO2 composites prepared by high-energy ball milling, J Alloys Compd., 491 (2010), 712-721, doi:10.1016/j.jallcom.2009.11.051

${ }^{5}$ K. Dash, B. C. Ray, D. Chaira, Synthesis and characterization of copper-alumina metal matrix composite by conventional and spark plasma sintering, J Alloys Compd, 516 (2012), 78-84, doi:10.1016/ j.jallcom.2011.11.136

${ }^{6}$ C. N. Machio, H. K. Chikwanda, S. Chikosha, Effect of process control agent (PCA) on the characteristics of mechanically alloyed Ti-Mg powders, J South Afr. Inst. Min. Metall., 111 (2011), 149-153

${ }^{7}$ U. Shreenag Meda, Rakesh., S. N. Sidharth, Chandra., B. R. Latha, Impact of particle size on content uniformity, Int J Innov. Res. Sci. Eng. Technol., 3 (2014), 9369-9374, doi:10.15680/IJIRSET.2015. 0402100

${ }^{8}$ P. Azadi, E. Afif, F. Azadi, R. Farnood, Screening of nickel catalysts for selective hydrogen production using supercritical water gasification of glucose, Green chem. 14 (2012), 1766-1777, doi:10.1039/C2GC16378K

${ }^{9}$ D. Jeyasimman, S. Sivasankaran, K. Sivaprasad, R. Narayanasamy, R. S. Kambali, An investigation of the synthesis, consolidation and mechanical behaviour of Al 6061 nanocomposites reinforced by TiC via mechanical alloying, Mater. Des. 57 (2014), 394-404. doi:10.1016/j.matdes.2013.12.067

${ }^{10}$ V. Sagarwankhede, L. Samirshinde, R. Amit Wasnik, Modelling of wear behaviour of copper alumina metal matrix composites prepared by PM Route, Int J Eng. Adv. Technol., 3 (2013), 330-332

${ }^{11}$ S. Hosseinpour, M. Forslund, C. Magnus Johnson, J. Pan, C. Leygraf, Atmospheric corrosion of $\mathrm{Cu}, \mathrm{Zn}$, and $\mathrm{Cu}-\mathrm{Zn}$ alloys protected by self-assembled monolayers of alkanethiols, Surf. Sci., 648 (2016), 170-176, doi:10.1016/j.susc.2015.10.045

${ }^{12}$ J. Winzer, L. Weiler, J. Pouquet, J. Rödel, Wear behaviour of interpenetrating alumina-copper composites. Wear, 271 (11-12), (2011), 2845-2851, doi:10.1016/j.wear.2011.05.042

${ }^{13}$ A. Molina, A. Torres-Islas, S. Serna, M. Acosta-Flores, R. A. Rodriguez-Diaz, J. Colin, Corrosion, electrical and mechanical performance of copper matrix composites produced by mechanical alloying and consolidation. Int J Electrochem. Sci., 10 (2015) 2, 1728-1741

${ }^{14} \mathrm{C}$. Koch, Intermetallic matrix composites prepared by mechanical alloying - a review. Mater. Sci. Eng: A, 244(1) (1998), 39-48, doi:10.1016/S0921-5093(97)00824-1

${ }^{15}$ K. K. Alaneme, B. U. Odoni, Mechanical properties, wear and corrosion behavior of copper matrix composites reinforced with steel machining chips. Int J Eng. Sci. Technol., 19 (2016) 3, 1593-1599, doi:10.1016/j.jestch.2016.04.006

${ }^{16}$ K. K. Alaneme, O. A. Ajibuwa, I. E. Kolawole, A. V. Fajemisin, Mechanical, corrosion and wear behaviour of steel chips and graphite reinforced $\mathrm{Zn}-27 \mathrm{Al}$ alloy based composites, Acta Metallurgica Slovaca, 23 (2017) 2, 171-181, doi:10.12776/ams.v23i2.865

${ }^{17}$ F. Akhtar, S. J. Guo, Microstructure, mechanical and fretting wear properties of TiC-stainless steel composites, Mater. Charac., 59 (2008), 84-90, doi:10.1016/j.matchar.2006.10.021

${ }^{18}$ M Djafri, M Bouchetara, C Busch, S Weber, Effects of humidity and corrosion on the tribological behaviour of the brake disc materials, Wear, 321(2014), 8-15, doi:10.1016/j.wear.2014.09.006

${ }^{19}$ K. Sang, Y. Weng, Z. Huang, X. Hui, H. Li, Preparation of interpenetrating alumina-copper composites, Ceramics Int., 42 (2016), 6129-6135, doi:10.1016/j.ceramint.2015.12.174

${ }^{20}$ A. Lara-Guevara, I. Rojas-Rodriguez, R. Velazquez-Hernandez, R. A. Bernal-Correa, A. Sierra-Gutierrez, A. Herrera-Ramos, M. E. Rodriguez-Garcia, Synthesis of copper-alumina composites by mechanical milling: An analysis, Mater. Manuf. Processes., 28 (2013), 157-162, doi:10.1080/10426914.2012.677899

${ }^{21}$ A. Pattanaik, M. Satpathy, S. Mishra, Dry sliding wear behavior of epoxy fly ash composite with Taguchi optimization, Engi. Sci. Technol, Int J, 19 (2016), 710-716, doi:10.1016/j.jestch.2015.11.010

${ }^{22}$ N. Perez, Corrosivity and passivity, Electrochemistry and Corrosion Science, Springer, 2004, doi:10.1007/1-4020-7860-9_6 